\title{
Pengaruh Kualitas Pelayanan, Persepsi Harga, Dan Kualitas Produk Terhadap Kepuasan Pelanggan Pada Sendy's Swalayan Palangka Raya
}

\author{
Nadia Putri Permata Ray Bimaria 1) \\ Drs. Murie P. Kulu, M.Si ${ }^{2) *}$ \\ Dra. Peridawaty, $\mathbf{M M}^{3}$ \\ Fakultas Ekonomi dan Bisnis \\ Universitas Palangka Raya, Indonesia \\ e-mail:nadiaputri@gmail.com
}

\begin{abstract}
Abstrak
Tujuan, - Penelitian ini bertujuan untuk mengetahui Pengaruh Kualitas pelayanan, persepsi harga dan kualitas produk terhadap kepuasan pelanggan pada Sendy's Swalayan Palangka Raya..

Desain/Methodologi/Pendekatan - Metode penelitian menggunakan pendekatan eksplanotory dengan teknik survey, jumlah sampel dalam penelitian ini adalah 100 orang responden, teknik pengambilan sampel menggunakan teknik Sensus.

Metode pengumpulan data menggunakan teknik Kuesioner dan studi dokumentasi, sedangkan teknik analisis data yang digunakan dalam penelitian ini adalah menggunakan teknik analisis deskriptif dan teknik analisis linear berganda.

Temuan penelitian - Hasil penelitian menunjukkan bahwa Pengaruh Kualitas pelayanan, persepsi harga dan kualitas produk terhadap kepuasan pelanggan pada Sendy’s Swalayan Palangka Raya. Dan pada hasil analisis deskriptif menyatakan bahwa responden setuju dengan indikator-indikator yang diajukan.
\end{abstract}

Kata kunci: Kualitas pelayanan, Persepsi Harga, Kualitas Produk, Kepuasan Pelanggan

\section{The Effect of Service Quality, Price Perception, and Product Quality on Customer Satisfaction at Sendy's Swalayan Palangka Raya}

\begin{abstract}
Purpose, - This study aims to determine the effect of service quality, price perception and product quality on customer satisfaction at Sendy's Swalayan Palangka Raya.

Design/methodology/approach - The research method uses an explanatory approach to techniques survey, the number of samples in this study were 100 respondents, the sampling technique using census techniques. Data collection methods using questionnaires and documentation studies, while data analysis techniques used in this research are descriptive analysis techniques and multiple linear analysis techniques.

Findings - The results showed that the influence of service quality, price perception and product quality on customer satisfaction at Sendy's Swalayan Palangka Raya. And the results of the descriptive analysis state that the respondents agreed with the proposed indicators.
\end{abstract}

\section{Keywords: : Service quality, Price Perception, Product Quality, Customer Satisfaction}

\section{JMED}

Jurnal Manajemen Sains dan Organisasi

Vol 1, No 3, 2020 pp. $181-191$

FEB UPR Publishing $2685-4724$
Nadia Putri Permata Ray Bimaria, Drs. Murie P. Kulu, M.Si, Dra. Peridawaty, MM3. Published in the Jurnal Manajemen sains dan Organsasi. Published by FEB UPR Publishing Limited. This article is published under the Creative Commons Attribution (CC BY 4.0) licence. Anyone may reproduce, distribute, translate and create derivative works of this article (for both commercial and non-commercial purposes), subject to full attribution to the original publication and authors. 


\section{PENDAHULUAN}

Dewasa ini banyak bermunculan perusahaan dagang yang bergerak pada bidang perdagangan eceran (retailing) yang berbentuk toko, mini market, department store (toserba), pasar swalayan (supermarket) dan lain-lain. Persaingan bisnis yang dihadapi perusahaanperusahaan semakin ketat, sehingga menuntut manajemen perusahaan untuk lebih cermat dalam menentukan strategi bersaing, agar dapat memenangkan persaingan. Untuk itu, perusahaan sebaiknya memanfaatkan peluang-peluang bisnis dan berusaha untuk menerapkan strategi pemasaran yang tepat dalam rangka untuk mengusai pasar. Bagi perusahaan, faktorfaktor penentu kesuksesan dalam menciptakan kesetiaan pada pelanggan adalah kepuasan terhadap kualitas yang diberikan (Tjiptono, 2008). Dengan demikian, kepuasan pelanggan, harga dan kualitas produk yang baik akan menciptakan, mempertahankan kepuasan serta menjadikan pelanggan yang loyal.

Kualitas Pelayanan adalah apabila hasil dari jasa yang digunakan sesuai dengan keinginan konsumen atau pelanggan. Harga adalah "jumlah uang (ditambah beberapa barang kalau mungkin) yang dibutuhkan untuk mendapatkan sejumlah kombinasi dari barang beserta pelayanannya" (Swastha, 2012). Kualitas produk adalah kemampuan sebuah produk dalam memperagakan fungsinya, hal ini termasuk keseluruhan durabilitas, reliabilitas, ketepatan, kemudahan pengoperasian, dan reparasi produk, juga atribut produk lainnya (Kotler dan Armstrong, 2012).

Kotler (2007), "kepuasan pelanggan adalah perasaan senang atau kecewa seseorang yang muncul setelah membandingkan antara kinerja (hasil) produk yang dipikirkan terhadap kinerja (hasil) yang diharapkan Ciri-ciri pelanggan yang puas antara lain yang selalu melakukan pembelian ulang secara terus menerus. kepuasan pelanggan secara umum dapat diartikan sebagai kesetiaan seseorang terhadap suatu produk, baik barang maupun jasa tertentu. Kepuasan pelanggan dalam menggunakan fasilitas maupun jasa pelayanan yang diberikan pihak perusahaan, serta tetap menjadi pelanggan dari perusahaan tersebut. Kepuasan pelanggan terjadi hanya pada saat patronase ulangan dan sikap relatif tinggi. Jika relatif rendah, maka dianggap sebagai loyalitas pelanggan yang semu (spunous loyality). Pelanggan dalam kondisi seperti ini sangat mungkin melakukan pembelian ulang hanya karena faktor-faktor situsional saja, nilai keterbatasan dana dan waktu. Sedangkan sikap yang tinggi tetapi tidak diikuti dengan patronase ulangan yang tinggi dianggap sebagai loyalitas pelanggan yang bersifat latent (latent loyalitas pelanggan). Namun, loyal atau tidak pelanggan terhadap suatu produk perusahaan sangat tergantung pada kemampuan manajemen perusahaan dalam mengelola faktor-faktor yang mempengaruhi kesetiaan pelanggan.

Penguasaan pasar merupakan salah satu dari kegiatan-kegiatan pokok yang dilaksanakan oleh para penguasa dalam usahanya untuk mempertahankan kelangsungan hidup usahanya, berkembang dan mendapatkan laba semaksimal mungkin serta membuat konsumen menjadi loyal. Hal tersebut bisa tercapai bila konsumen merasa puas akan kinerja produk yang ditawarkan oleh pengusaha. Menurut Hardiwan dan Mahdi (2005) kualitas produk yang baik akan menciptakan, mempertahankan kepuasan pelanggan serta menjadikan konsumen yang loyal, disamping itu harga juga mempunyai pengaruh yang besar juga terhadap loyalitas pelanggan.

Perusahaan yang bergerak dibidang retail harus berupaya untuk memberikan kepuasan kepada pelanggan, sebab kalau pelanggan merasa puas maka dapat menarik dan mempertahankan konsumen. Persaingan bisnis ritel sekarang ini sangat tinggi sehingga tidak jarang bisa ditemui dalam satu lokasi terdapat 3 atau 4 supermaket, kompetisi dalam bisnis ritelpun berubah, karena secara tiba-tiba bermunculan pesaing-pesaing baru, karena itulah 
pola konsumen pun ikut berubah dan harapan konsumen sangat tinggi, konsumen mengharapkan barang yang baik dengan harga relatif murah, pelayanan yang prima serta suasana belanja yang menyenangkan karena itulah dengan prioritas konsumen yang berubah, perusahaanpun mau tidak mau harus mempunyai desain bisnis yang disesuikan, model operasional yang harus disesuaikan dan perusahaan terus berkonsertasi dimana mereka harus berfokus.

Dari hal tersebut itulah dapat dilihat bagaimana masing-masing supermarket dan sejenis berusaha menarik pembeli untuk datang ke toko dan berbelanja. Para penjual berusa memaksimalkan beberapa komponen penting yang dianggap sangat mempengaruhi kelangsungan bisnis yang dijalankan. Secara tidak langsung dapat dilihat bagaimana penjual bersaing dalam masalah kualitas dan kuantitas produk, harga yang kompetitif, ,dan dapat memberi kepuasan kepada pelanggan

\section{TINJAUAN PUSTAKA}

\section{Pengertian Kualitas}

Dalam ISO 8402 (Quality Vocabulary),kualitas didefinisikan sebagai totalitas dari karakteristik suatu produk yang menunjang kemampuannya untuk memuaskan kebutuhan yang dispesifikasikan atau ditetapkan. Kualitas sering diartikan sebagai kepuasan pelanggan (customer statisfaction) atau konformansi terhadap kebutuhan atau persyaratan (conformance to the requirement) disamping pengertian kualitas seperti seperi telah disebutkan diatas, juga dapat diartikan sebagai sesuatu yang diartikan sebagai segala sesuatu yang menentukan kepuasan pelanggan dan upaya perubahan kearah perbaikan terus menerus sehingga dikenal istilah Q-MATCH (Quality- Meet Agreed Term and Changes)

Berdasarkan definisi tentang kualitas baik yang konvensional maupun yang lebih strategik, kita boleh menyatakan bahwa pada dasarnya kualitas mengacu kepada pengertian pokok sebagai berikut:

1. Kualitas terdiri dari sejumlah keistimewaan produk, baik keistimewaan langsung maupun keistimewaan atraktif yang memenuhi keinginan pelanggan dan dengan demikian memberikan kepuasan atas penggunaan produk itu.

2. Kualitas terdiri dari segala sesuatu yang bebas dari kekurangan atau kerusakan.

Berdasarkan pengertian dasar tentang kualitas diatas, tampak bahwa kualitas selalu berfokus pada pelanggan (Customer focused quality). Dengan demikian produk-produk didesain, diproduksi, serta pelayanan yang diberikan untuk memenuhi keinginan pelanggan. Karena kualitas mengacu kepada segala sesuatu yang menentukan kepuasan pelanggan, suatu produk yang dihasilkan baru dapat dikatakan berkualitas apabila sesuai dengan keinginan pelanggan, dapat dimanfaatkan dengan baik, serta diproduksi (dihasilkan) dengan cara yang baik dan benar.

Kualitas produk adalah kemampuan sebuah produk dalam memperagakan fungsinya, hal ini termasuk keseluruhan durabilitas, reliabilitas, ketepatan, kemudahan pengoperasian, dan reparasi produk, juga atribut produk lainnya (Kotler dan Armstrong, 2012).

\section{Persepsi Harga}

Harga adalah "jumlah uang (ditambah beberapa barang kalau mungkin) yang dibutuhkan untuk mendapatkan sejumlah kombinasi dari barang beserta pelayanannya" (Swastha, 2012). Harga "adalah sejumlah uang yang dibutuhkan untuk mendapatkan sejumlah barang beserta jasa-jasa tertentu atau kombinasi dari keduanya" (Gitosudarmo,2001). Dalam penelitian ini, harga adalah nilai suatu barang atau jasa yang diukur dengan sejumlah uang. 
Pada umumnya penjual mempunyai beberapa tujuan dalam penetapan harga produknya. Ada 4 jenis tujuan penetapan harga, yaitu:

a. Tujuan berorientasi pada laba

Asumsi teori ekonomi klasik menyatakan bahwa setiap perusahaan selalu memilih harga yang dapat menghasilkan laba paling tinggi, tujuan ini dikenal dengan istilah maksimasi laba.

b. Tujuan berorientasi pada volume

Selain tujuan berorientasi pada laba, ada pula perusahaan yang menetapkan harganya berdasarkan tujuan yang berorientasi pada volume tertentu atau yang biasa dikenal dengan istilah volume pricing objectives.

c. Tujuan berorientasi pada citra

Citra (image) suatu perusahaan dapat dibentuk melalui strategi penetapan harga.

Perusahaan dapat menetapkan harga tinggi untuk membentukataumempertahankancitra prestisius.

d. Tujuan stabilisasi harga

Pada pasar yang konsumennya sangat sensitif terhadap harga, bila suatu perusahaan menurunkan harganya, maka para pesaingnya harus menurunkan harga mereka

e. Tujuan-tujuan lainnya

Harga dapat pula ditetapkan dengan tujuan mencegah masuknya pesaing, mempertahankan loyalitas pelanggan, mendukung penjualan ulang, atau menghindari campur tangan pemerintah (Tjiptono, 2014).

Pengertian Kualitas Produk

Produk memiliki arti penting bagi perusahaan karena tanpa adanya produk, perusahaan tidak akan dapat melakukan apapun dari usahanya. Pembeli akan membeli produk kalau merasa cocok, karena itu produk harus disesuaikan dengan keinginan ataupun kebutuhan pembeli agar pemasaran produk berhasil. Dengan kata lain, pembuatan produk lebih baik diorientasikan pada keinginan pasar atau selera konsumen. Menurut Kotler dan Amstrong (2012) adalah "Segala sesuatu yang dapat ditawarkan ke pasar untuk mendapatkan perhatian, dibeli, digunakan, atau dikonsumsi yang dapat memuaskan keinginan atau kebutuhan".

Mc Charty dan Perreault (2009) mengemukakan bahwa, "Produk merupakan hasil dari produksi yang akan dilempar kepada konsumen untuk didistribusikan dan dimanfaatkan konsumen untuk memenuhi kebutuhannya". Sedangkan menurut Saladin (2002), "Produk adalah segala sesuatu yang dapat ditawarkan ke suatu pasar untuk diperhatikan, dimiliki, dipakai atau dikonsumsi sehingga dapat memuaskan keinginan dan kebutuhan".

Menurut Kotler (2007), "Kualitas produk adalah keseluruhan ciri serta dari suatu produk atau pelayanan pada kemampuan untuk memuaskan kebutuhan yang dinyatakan/ tersirat". Sedangkan menurut Lupiyoadi (2014) menyatakan bahwa "Konsumen akan merasa puas bila hasil evaluasi mereka menunjukkan bahwa produk yang mereka gunakan berkualitas “.

1. Atribut Produk

Menurut Kotler dan Armstrong (2012) beberapa atribut yang menyertai dan melengkapi produk (karakteristik atribut produk) adalah:

a. Merek (Brand)

Merek (Brand) adalah nama, istilah, tanda, simbol, atau rancangan, atau kombinasidari semua ini yang dimaksudkan untuk mengidentifikasi produk atau jasa dari satu atau kelompok penjual dan membedakannya dari produk pesaing. Pemberian 
merek merupakan masalah pokok dalam strategi produk. Pemberian merek itu mahal dan memakan waktu, serta dapat membuat produk itu berhasil atau gagal. Nama merek yang baik dapat menambah keberhasilan yang besar pada produk (Kotler dan Armstrong, 2012)

b. Pengemasan (Packing)

Pengemasan (Packing) adalah kegiatan merancang dan membuat wadah atau pembungkus suatu produk.

c. Kualitas Produk (Product Quality)

Kualitas Produk (Product Quality) adalah kemampuan suatu produk untuk melaksanakan fungsinya meliputi, daya tahan keandalan, ketepatan kemudahan operasi dan perbaikan, serta atribut bernilai lainnya. Untuk meningkatkan kualitas produk perusahaan dapat menerapkan program "Total Quality Manajemen (TQM)". Selain mengurangi kerusakan produk, tujuan pokok kualitas total adalah untuk meningkatkan nilai pelanggan.

2. Tingkatan Produk

Berdasarkan definisi diatas produk dapat dikatakan sebagai fokus inti dari semua bisnis. Produk adalah apa yang dilakukan perusahaan, mulai dari mendesain, mengadakan sistem produksi dan operasi, menciptakan program pemasaran, sistem distribusi, iklan dan mengarahkan tenaga penjual untuk menjual produk tersebut.

Menurut Kotler dan Armstrong (2012) dalam merencanakan penawaran suatu produk, pemasar harus memahami lima tingkat produk, yaitu :

a. Produk Utama (Care Benefit), yaitu manfaat yang sebenarnya dibutuhkan dan akan dikonsumsi oleh pelanggan dari setiap produk.

b. Produk Generik (Basic Produk), adalah produk dasar yang mampu memenuhi fungsi pokok produk yang paling dasar.

c. Produk Harapan (Expected Product), adalah produk formal yang ditawarkan dengan berbagai atribut dan kondisi secara normal (layak) diharapkan dan disepakati untuk dibeli.

d. Produk Pelengkap (Augment Product), adalah berbagai atribut produk yang dilengkapi atau ditambahkan dengan berbagai manfaat dan layanan, sehingga dapat memberikan tambahan kepuasan dan dapat dibedakan dengan produk pesaing.

e. Produk Potensial (Potential Product), adalah segala macam tambahan dan perubahan yang mungkin dikembangkan untuk suatu produk dimasa mendatang.

3. Klasifikasi Produk

Menurut Kotler dan Armstrong (2012) klasifikasi produk dibagi menjadi dua bagian, yaitu :

a. Barang Konsumen

Barang konsumen yaitu barang yang dikonsumsi untuk kepentingan konsumen akhir sendiri, bukan untuk tujuan bisnis. Umumnya barang konsumsi dapat diklasifikasikan menjadi empat jenis, yaitu :

a. Barang kebutuhan sehari-hari (Convience Goods) adalah barang-barang yang biasanya sering dibeli konsumen (memiliki frekuensi pembelian tinggi), dibutuhkan dalam waktu segera, dan memerlukan waktu yang minim dalam pembandingan dan pembeliannya.

b. Barang belanjaan (Shopping Goods) adalah barang-barang yang karakteristiknya dibandingkan dengan berbagai alternatif yang tersedia oleh konsumen berdasarkan kesesuaian, kualitas, harga, dan daya dalam proses pemilihan dan pembeliannya. 
c. Barang khusus (Speciality Goods) adalah barang-barang dengan karakteristik dan atau identifikasi yang unik, yang untuknya sekelompok pembeli yang cukup besar bersedia senantiasa melakukan usaha khusus untuk pembeliannya.

d. Barang yang tidak dicari (Unsought Goods) adalah barang-barang yang tidak diketahui konsumen atau walau sudah diketahui namun secara umum konsumen belum terpikir untuk membelinya.

b. Barang Industri

Barang industri adalah barang-barang yang dikonsumsi oleh industriawan (konsumen antara atau konsumen bisnis) untuk keperluan selain konsumsi langsung, yaitu : untuk diubah, diproduksi menjadi barang lain kemudian dijual kembali oleh produsen, untuk dijual kembali oleh pedagang tanpa dilakukan transformasi fisik (proses produksi).

4. Dimensi Kualitas Produk

Menurut Orville, Larreche, dan Boyd (2005) apabila perusahaan ingin mempertahankan keunggulan kompetitifnya dalam pasar, perusahaan harus mengerti aspek dimensi apa saja yang digunakan oleh konsumen untuk membedakan produk yang dijual perusahaan tersebut dengan produk pesaing. Dimensi kualitas produk yaitu:

a) Performance (kinerja), berhubungan dengan karakteristik operasi dasar dari sebuah produk.

b) Durability (daya tahan), yang berarti berapa lama atau umur produk yang bersangkutan bertahan sebelum produk tersebut harus diganti. Semakin besar frekuensi pemakaian konsumen terhadap produk maka semakin besar pula daya tahan produk.

c) Conformance to Specifications (kesesuaian dengan spesifikasi), yaitu sejauh mana karakteristik operasi dasar dari sebuah produk memenuhi spesifikasi tertentu dari konsumen atau tidak ditemukannya cacat pada produk.

d) Features (fitur), adalah karakteristik produk yang dirancang untuk menyempurnakan fungsi produk atau menambah ketertarikan konsumen terhadap produk.

e) Reliabilty (reliabilitas), adalah probabilitas bahwa produk akan bekerja dengan memuaskan atau tidak dalam periode waktu tertentu. Semakin kecil kemungkinan terjadinya kerusakan maka produk tersebut dapat diandalkan.

f) Aesthetics (estetika), berhubungan dengan bagaimana penampilan produk bisa dilihat dari tampak, rasa, bau, dan bentuk dari produk.

g) Perceived Quality (kesan kualitas), sering dibilang merupakan hasil dari penggunaan pengukuran yang dilakukan secara tidak langsung karena terdapat kemungkinan bahwa konsumen tidak mengerti atau kekurangan informasi atas produk yang bersangkutan. Jadi, persepsi konsumen terhadap produk didapat dari harga, merek, periklanan, reputasi, dan Negara asal.

\section{METODE PENELITIAN}

Teknik pengambilan sampel yang digunakan adalah Non Probability sampling. Metode yang dipakai purposive sampling, yaitu teknik penentuan sampel dengan pertimbangan tertentu (Sugiono,2008). Berdasarkan teknik tersebut, maka penarikan sampel dilakukan dengan cara memilih siapa saja yang mudah didapatkan di lapangan dengan syaratsyarat (kriteria) tertentu yaitu:

1. Pengunjung Sendy's Swalayan Palangka Raya yang sedang berbelanja pada saat pengambilan data. 
2. Pengunjung yang sudah mempunyai penghasilan yang sedang berbelanja pada Sendy's Swalayan Palangka Raya.

3. Pengunjung yang pernah berbelanja minimal dua kali di Sendy's Swalayan Palangka Raya

Analisis yang digunakan untuk menghasilkan gambaran dari data yang telah terkumpul berdasarkan jawaban responden adalah melalui distribusi item dari masing - masing variabel. Penyajian data yang telah terkumpul dilakukan menggunakan tabel frekuensi.

Untuk mengetahui pengaruh dari variabel independen $(\mathrm{X})$ terhadap variabel dependen (Y), baik secara simultan maupun parsial digunakan persamaan Regresi Linier Berganda dengan rumus sebagai berikut :

$$
\mathrm{Y}=\alpha+\mathrm{b} 1 \mathrm{X} 1+\mathrm{b} 2 \mathrm{X} 2+\mathrm{b} 3 \mathrm{X} 3+\mathrm{e}
$$

Keterangan :

ba : Konstanta

b1 s/d b3 : Koefisien regresi

X1 : Kualits palayanan

X2 : Persepsi Harga

X3 : Kualitas Produk

Y : Kepuasan pelanggan

e : error/ pengaruh faktor lain

Uji t digunakan untuk mengetahui pengaruh masiang-masing variabel independent terhadap variabel dependent. Pengujian dilakukan dengan cara melihat nilai signifikan thitung. jika nilai signifikan thitung $<$ dari 0,05 maka variable independent secara Parsial mempunyai pengaruh signifikan terhadap variabel defendent, dan sebaliknya jika nilai signifikansi thitung $>$ dari 0,05 maka variabel independen secara Parsial tidak mempunyai pengaruh signifikan terhadap variabel dependent. Disamping itu uji t juga digunakan untuk mengetahui seberapa besar kontribusi masing-masing variabel independent tersebut terhadap variabel dependent, yaitu dengan melihat besarnya $\mathrm{r} 2$ parsial setiap variabel. Dari angka yang diperoleh dapat diketahui variabel independent mana yang mempunyai kontribusi besar dan signifikan terhadap variabel dependent.

Uji $F$ digunakan untuk menguji pengaruh variabel independent secara simultan terhadap variabel dependent. Pengujian dilakukan dengan cara melihat nilai signifikan Fhitung. Jika nilai signifikansi Fhitung $<$ dari 0,05 maka variable independen secara simultan mempunyai pengaruh signifikan terhadap variabel dependent, dan sebaliknya jika nilai signifikansi Fhitung $>$ dari 0,05 maka variabel independent secara simultan tidak mempunyai pengaruh signifikan terhadap variabel dependent.

Koefisien determinasi $R 2$ pada intinya mengukur seberapa jauh kemampuan model dalam menerangkan variasi variabel dependen.Nilai koefisien determinasi adalah antara nol dan satu.Nilai $R 2$ yang kecil berarti kemampuan variabel- variabel independen dalam menjelaskan variasi variabel dependen amat terbatas.Nilai yang mendekati satu berarti variabel-variabel independen memberikan hampir semua informasi yang dibutuhkan untuk memprediksi variasi variabel dependen. Ghozali (2011). 


\section{HASIL PENELITIAN}

Persamaan Regresi Linear Berganda

Tabel 1. Hasil Analisis Regresi Linier Berganda

\begin{tabular}{|c|c|c|c|c|c|}
\hline \multirow[t]{2}{*}{ Model } & \multicolumn{2}{|c|}{ Unstandardized Coefficients } & \multirow{2}{*}{\begin{tabular}{|c|}
$\begin{array}{r}\text { Standardized } \\
\text { Coefficients }\end{array}$ \\
Beta
\end{tabular}} & \multirow{2}{*}{$\mathrm{t}$} & \multirow[b]{2}{*}{ Sig. } \\
\hline & $\mathrm{B}$ & Std. Error & & & \\
\hline $\begin{array}{l}\text { (Constant) } \\
\text { Kualitas Pelayanan } \\
\text { (X1)Presepsi Harga } \\
\text { (X2) Kualitas Produk } \\
\text { (X3) }\end{array}$ & $\begin{array}{l}.151 \\
.192 \\
.319 \\
.483\end{array}$ & $\begin{array}{l}.389 \\
.087 \\
.105 \\
.087\end{array}$ & $\begin{array}{l}.175 \\
.248 \\
.468\end{array}$ & $\begin{array}{r}.387 \\
2.215 \\
3.029 \\
5.546\end{array}$ & $\begin{array}{r}.700 \\
.029 \\
.003 \\
.000\end{array}$ \\
\hline
\end{tabular}

a. Dependent Variable: Kepuasan Pelanggan (Y)

Berdasarkan tabel di atas dapat ditentukan model regresi linear berganda yang dinyatakan dalam bentuk persamaan sebagai berikut:

Keterangan:

$$
\mathrm{Y}=0.151+0.192 \mathrm{X} 1+0.319 \mathrm{X} 2+0.483 \mathrm{X} 3+\mathrm{e}
$$

$\mathrm{Y}=$ Kepuasan Pelanggan

$\mathrm{X} 1$ = Kualitas Pelayanan

$\mathrm{X} 2$ = Persepsi Harga

X3 = Kualitas Produk

Dari nilai persamaan regresi diatas dapat diketahui bahwa:

1. Konstanta sebesar 0.151 artinya jika Variabel Kualitas Pelayanan, Presepsi Harga,Kualitas produk konstan atau tetap, maka nilai Kepuasan pelanggan adalah 0.151 atau bila dipersentasikan sebesar 15,1\%

2. Nilai Koefisien Regresi untuk variabel Kualitas Pelayanan Positif pada persamaan regresi menunjukan nilai positif sebesar 0,192, artinya jika jika Variabel Kualitas Pelayanan meningkat sebesar 1 satuan maka nilai kepuasan pelanggan akan meningkat 0,192, dengan kata lain, besarnya pengaruh variabel prodiuct terhadap keputusan pembelian adalah 0,192 atau 19,2\%.

3. Nilai Koefisien Regresi untuk variable Persepsi Harga Positif pada persamaan regresi menunjukan nilai positif sebesar 0,319 artinya jika variabel persepsi harga meningkat sebesar 1 satuan maka nilai kepuasan pelanggan akan meningkat 0,319, dengan kata lain, besarnya pengaruh variabel persepsi harga terhadap kepuasan pelanggan adalah adalah 0,319 atau $31,9 \%$.

4. Nilai Koefisien Regresi untuk variabel Kualitas produk Positif pada persamaan regresi menunjukan nilai positif sebesar 0,483 artinya jika jika Variabel kualitas produk meningkat sebesar 1 satuan maka nilai kepuasan pelanggan akan meningkat 0,483, dengan kata lain, besarnya pengaruh variabel kualitas produk terhadap kepuasan pelanggan adalah 0,483 atau $48,3 \%$. 
Uji Hipotesis

a. Uji t (Parsial)

Tabel 2. Uji T ( Uji Parsial)

\begin{tabular}{|ll|r|r|}
\hline \multicolumn{1}{|c|}{ Model } & $\mathrm{t}$ & \multicolumn{1}{l|}{ Sig. } \\
\cline { 2 - 5 } & (Constant) & .387 & .700 \\
& Kualitas pelayanan (X1) & 2.215 & .029 \\
& Persepsi harga (X2) & 3.029 & .003 \\
& Kualitas Produk (X3) & 5.546 & .000 \\
\hline
\end{tabular}

a. Dependent Variable: Y

Koefisien dari variabel Kualitas produk (X1) adalah signifikan pada $\alpha=0,05$, karena karena $t$ hitung $>\mathrm{t}$ tabel $(2,215>1,980)$ atau nilai sig. $0,029<0,05$. Artinya pengaruh variabel Kualitas produk terhadap kepuasan pelanggan adalah signifikan. Berarti hipotesis yang menyatakan bahwa Kualitas produk berpengaruh terhadap kepuasan pelanggan bisa diterima. Koefisien dari variabel Persepsi Harga (X2) adalah signifikan pada $\alpha=0,05$, karena t hitung $>$ t tabel $(3.029>1,980)$ atau nilai sig. $0,003<0,05$. Artinya pengaruh variabel Persepsi Harga terhadap kepuasan pelanggan adalah signifikan. Berarti hipotesis yang menyatakan bahwa Persepsi Harga berpengaruh terhadap kepuasan pelanggan bisa diterima. Koefisien dari variabel kualitas produk (X3) adalah signifikan pada $\alpha=0,05$, karena $\mathrm{t}$ hitung $>\mathrm{t}$ tabel (5.546 $>1,980$ ) atau nilai sig. $0,000<0,05$. Artinya pengaruh variabel kualitas produk terhadap kepuasan pelanggan adalah signifikan. Berarti hipotesis yang menyatakan bahwa kualitas produk berpengaruh terhadap kepuasan pelanggan bisa diterima.

b. Uji F (Simultan)

Tabel 3. Uji Simultan (Uji F)

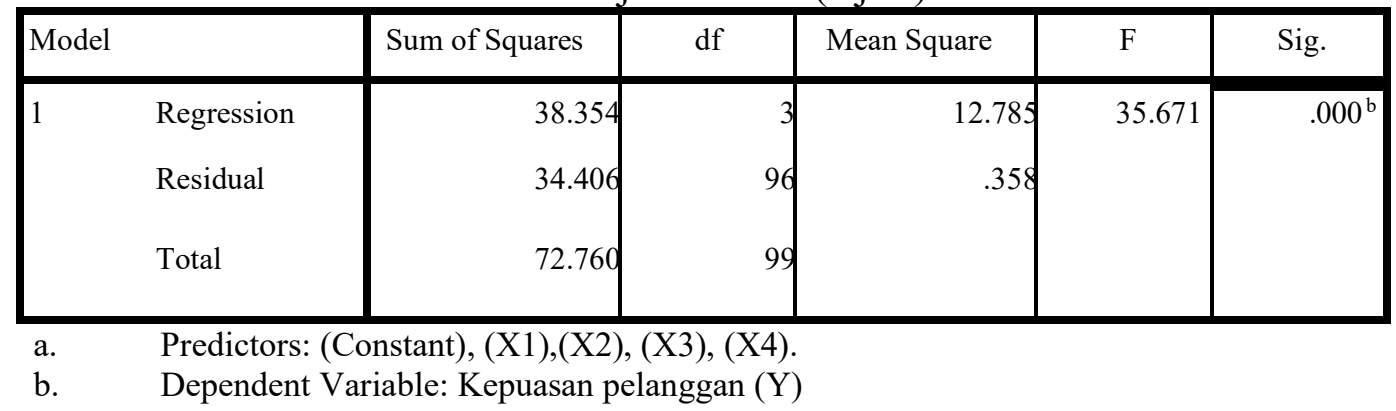

Uji ini digunakan dengan tujuan untuk membuktikan apakah variabel bebas berpengaruh secara bersama-sama terhadap variabel terikat. Dari hasil perhitungan melalui SPSS menunjukkan Fhitung sebesar 35.671 dan Ftabel = 2,20 (dengan menggunakan tingkat signifikasi $0,05 \%$ serta derajat kebebasan $(\mathrm{df}) ; \mathrm{n}-(\mathrm{k}+1) ; 100-(4+1)=95)$. Ini menyatakan bahwa fhitung (35.671) > Ftabel $(2,20)$ sehingga hipotesis diterima. Artinya bahwa variabel bebas yang terdiri dari kualitas pelayanan (X1), persepsi harga (X2), dan kualitas produk (X3) secara simultan berpengaruh terhadap kepuasan pelanggan Sendy"s Swalayan di Palangka Raya. 
Koefisien Determinasi (R2)

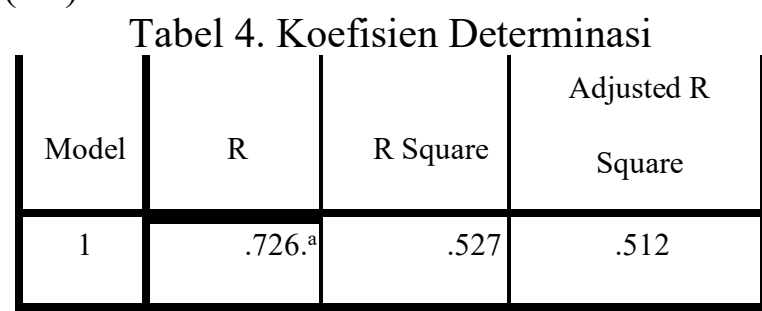

a.Predictors:(Constant), Kualitas pelayanan (X1),Persepsi harag (X2), kualitas produk (X3)

b. Dependent Variable: Kepuasan pelanggan (Y)

Nilai koefisien determinasi adjusted (R2) sebesar 0,527 menunjukkan bahwa variasi kepuasan pelanggan dijelaskan oleh variabel kualitas pelayanan, persepsi harga dan kualitas produk sebesar 52,7\% sementara 47,3\% dijelaskan oleh variabel lain yang tidak dianalisis dalam model.

Secara Umum Penelitian ini dapat menjelaskan hasil analisis deskriptif yang menunjukkan kondisi penelitian responden terhadap variabel-variabel penelitian memuaskan. Hal tersebut dapat dilihat dari hasil Pengaruh kualitas pelayanan, persepsi harga dan kualitas produk terhadap kepuasan pelanggan pada Sendy's Swalayan Palangka Raya. Dalam variabel kualitas pelayanan (X1) diperoleh nilai rata-rata sebesar 3,61, persepsi harga (X2) diperoleh nilai rata-rata sebesar 3,72, dan kualitas produk (X3) diperoleh nilai rata-rata sebesar 3,63. Berikut ini akan dijelaskan bahwa variabel independen yaitu kualitas pelayanan, persepsi harga dan kualitas produk. memiliki pengaruh terhadap kepuaan pelanggan baik secara parsial maupun simultan.

Implikasi Penelitian

Dari hasil uji hipotesis diatas terbukti bahwa bauran pemasaran yang terdiri dari kualitas pelayanan (X1) , persepsi harga (X2) dan kualitas produk (X3) berpengaruh terhadap kepuasan pelanggan pada Sendy's Swalayan Palangka Raya. Hal ini dapa dilihat dari hasil uji t dimana variabel kualitas pelayanan (X1), persepsi harga (X2) dan kualitas produk (X3) secara parsial mempunyai nilai $t$ hitung $>$ dari t tabel, atau dengan kata lain bahwa nilai sig dari variabel kualitas pelayanan (X1), persepsi harga (X2) dan kualitas produk (X3) adalah lebih kecil dari nilai alpha 0,05 .

Sedangkan dilihat secara simultan terdapat pula pengaruh antara variabel kualitas pelayanan (X1), persepsi harga (X2) dan kualitas produk (X3) terhadap kepuasan pelanggan. Hal ini dapat dibuktikan dengan statistik uji f yang dari analisisnya telah diperoleh hasil yang signifikan. Adapun besarnya kontribusi dari variabel kualitas pelayanan (X1), persepsi harga (X2) dan kualitas produk (X3) terhadap kepuaan pelanggan adalah sebesar 0,527 artinya sama dengan 52,7 \% sedangkan sisanya 47,3\% dipengaruhi oleh variabel lain diluar model.

Hal ini sesuai dengan penelitian Nadya Rizqyatul Faizah, Sri Suryoko, dan Suryadi (2013) dengan judul penelitian Pengaruh Harga ,Kualitas produk dan Kualitas pelayanan terhadap kepuasan pelanggan restauran O-MAMAIA STEAK AND ICE CREAM cabang jati Semarang. Hasil Berdasarkan Hasil peneelitian diketahui harga mempunyai pengaruh terhadap Kepuasaan Pelanggan, dimana nilai t Hitung lebih besar dari t tabel. Kualita Produk mempunyai pengaruh terhadap Kepuasan pelanggan dengan $t$ hitung $>t$ tabel, kualita produk berpengaruh positif dan signifikan terhadap kepuasan pelanggan $t$ hitung $>t$ tabel. Nilai koefisien Determinasi sebesar 42,2\%.

\section{DAFTAR PUSTAKA}

Adrian Payne. (2014). Services Marketing Pemasaran Jasa, Yogyakarta: Andi Yogyakarta. 
Asri, Marwan. (2009). Marketing. Edisi Ketiga. Yogyakarta: Penerbit UPP-AMP YKPN

Basu, Swastha DH., Irawan. (2012). Manajemen Pemasaran Modern Edisi ke-2. Yogyakarta: Liberty Offset.

Belch, George and Michael Belch. (2007). Advertising And Promotion: An Integrated Communication Perspective. (7th ed). New York: McGraw Hill

Cannon, Perreault dan McCarthy. (2009). Pemasaran Dasar Pendekatan Manajerial Global Buku 2 Edisi 16. Jakarta: Salemba Empat

Cooper, D. R. dan Pamela, S. S. (2013). Business Research Method Eight Edition. New York: McGraw Hill.

Ghozali, Imam. (2011). Aplikasi Analisis Multivariate Dengan Program SPSS. Semarang: Badan Penerbit Universitas Diponegoro.

Gitosudarmono, Indriyo. (2001). Pengantar Bisnis. BPFE, Yogyakarta.

Hardiwan, Febra dan Imam Mahdi. (2005). Faktor-Faktor yang Mempengaruhi Kesetiaan Konsumen Terhadap Sebuah Merek Rokok. Fokus Manajerial, Vol.3 No.1.

Jerry C. Olson dan Peter J. Paul. (2014). Perilaku konsumen dan strategi pemasaran. Edisi Sembilan. Buku 2.penerbit salemba empat.jakarta.

Kotler. (2007). Manajemen Pemasaran. Jakarta : Erlangga

Kotler, Philip. (2002). Manajemen Pemasaran Edisi Milenium. Jilid 1. Jakarta: Prenhallindo.

Kotler, philip \& Armstrong, Gary. (2012). Prinsip-prinsip pemasaran.Edisi 13.Jilid 1.Jakarta:Erlangga

Levy, M., \& Weitz, B. A. (2012). Retailing Management Information Center.New York: McGraw Hill Higher Education.

Lucas, D.B \& Britt, S.H. (2003). Advertising Psychology and Research. New York: Mc GrawHill.

Lupiyoadi, Rambat. (2014). Manajemen Pemasaran Jasa. Edisi 3. Jakarta:Salemba Empat.

Malhotra, Naresh K., and David F. Birks. 2012. Marketing Research: An Applied Approach 3rd European Edition. Harlow, England: Prentice-Hall

Mullins Jhon W, C. Orville, Jean-Claude Larreche, dan Harper W Walker Boyd. (2005). Manajemen Pemasaran . Jakarta: Erlangga.

Mowen, John C dan Michael Minor. (2002). Perilaku Konsumen. Jilid 1 dan 2 Edisi Kelima Alih Bahasa Lina Salim, Erlangga, Jakarta.

Nirwana (2012), Pemasaran Jasa, Penerbit Alta, Jakarta.

Parasuraman, V. A. (2011). A Conceptual Model of Service Quality and Its Implication forr Future Reaserch. Service Quality, 2015-220.

Singarimbun, Masri dan Effendi, Sofian (Editor). (2011). Metode Penelitian Survay. Jakarta: PT Pustaka LP3ES Indonesia.

Sugiono. (2008). Methode Penelitian Bisnis. Cetakan Kesembilan. Alfabeta. Bandung.

Supranto, J. Prof. (2004). Analisis Multivariat: Arti dan Interprestasi. PT. Asdi Mahasatya Jakarta.

Supranto, J. (2011). Pengukuran Tingkat Kepuasan Pelanggan Untuk Menaikkan Pangsa Pasar, Cetakan keempat, Penerbit PT Rineka Cipta, Jakarta.

Stanton, William J. (2002). Prinsip Pemasaran. Alih Bahasa oleh Sadu Sundaru. Jilid Satu. Edisi Kesepuluh. Jakarta : Erlangga.

Tjiptono, Fandy. (2008). Strategi Pemasaran, Edisi II, Andi Yogyakarta.

Tjiptono, Fandy. (2014). Pemasaran Jasa. Yogyakarta: Penerbit Andi.

Winardi. (2000). Pemasaran Jasa dan Implementasi. Yogyakarta: Ekonisia. 